\title{
Psychological Distress in California: Identifying Those at Greatest Risk
}

\author{
Gina Marie Piane \\ Department of Community Health, National University, Costa Mesa, CA, USA \\ Email: gpiane@nu.edu
}

Received 4 July 2014; revised 1 August 2014; accepted 14 August 2014

Copyright (C) 2014 by author and Scientific Research Publishing Inc.

This work is licensed under the Creative Commons Attribution International License (CC BY). http://creativecommons.org/licenses/by/4.0/

(c) (i) Open Access

\begin{abstract}
In order to address the unmet need for prevention and treatment of psychological distress and mental disorders, program planners and treatment providers need to identify individuals at high risk. The results of the California Health Interview Survey from $2009(n=47,614)$ indicate that there are high relative risks by demographics and smoking status for reports of psychological distress and intermediate measures: feeling nervous, hopeless, worthless, depressed, restless, and that everything is an effort. Specific demographic factors and smoking status can predict a greater need for prevention and treatment of psychological distress and lack of insurance coverage for treatment. Profiles associated with high risk can help in referral for diagnosis or to plan prevention programs.
\end{abstract}

\section{Keywords}

Psychological Distress, Demographics, Relative Risk, Smoking

\section{Introduction}

According to the 1999 Surgeon General's report, “Mental health is fundamental to health” and therefore mental health promotion is fundamental to health promotion. Mental disorders are often chronic and disabling. There is a great unmet need for prevention and treatment of mental disorders. Identifying groups at higher risk of mental disorders can both give evidence for the need and give direction to prevention and treatment efforts.

\subsection{Psychological Distress}

Serious psychological distress is a precursor to serious mental illness like depression and anxiety disorders and is a risk factor for suicide. Distress is also a risk factor for cardiovascular diseases and injuries. Distress can lengthen recovery from a variety of illnesses and injuries. Serious psychological distress is prevalent and de- 
structive.

\subsection{Demographic Factors and Psychological Distress}

It has been established in the professional literature that psychiatric disorders and their precursors do not occur evenly among the population. Disparities in mental health mirror some of the established risk factors for poor physical health in the US. Physical health diminishes with age and members of minority communities are at greater risk of disability and early death. Risk factors for depression, serious psychiatric distress and chronic mental disorders also include older age [1] [2] and minority status [3]. Additional risk factors are less education, being unmarried, unemployment, low income [4], lack of health insurance [1] and gender [5].

Extensive research regarding gender differences and health disparities by gender clearly indicates that men and women have different mental and physical health problems. It is also believed that gender differences in mental health contribute to gender differences in physical health. Needham asserts that women have more internalizing mental disorders as well as excess arthritis, headaches and gallbladder removal, while men have more externalizing mental disorders as well as excess heart disease and high blood pressure [5].

Examining physical and mental health disparities is truly artificial since mental health disorders often occur simultaneously with diabetes, cardiac disease and arthritis in older adults [2]. In addition to highly prevalent physical disorders in older adults, "One in four adults lives with depression, anxiety disorders or other significant psychiatric disorder" [2]. As the population ages there is an increased need for mental health services and the difficulties of aging are exacerbated by limited access to mental health services [2].

The unmet need for mental health services is compounded by the lack of preventive mental health interventions. In an editorial published in December 2010, Perry, Presley-Cantrell and Dhingra [6] recommend an integrated approach to achieving total health for a population in which physical and mental health are comprehensive including primary care, mental health and public health. It is one thing to declare that something should be done and another to provide evidence regarding how it should be done. To this end, Salum [7] convinces that there is an urgent need for investigations on preventive interventions in individuals at risk for mental disorders.

\subsection{Smoking and Psychological Distress}

In addition to the need for interventions to prevent mental disorders, it is equally important to enhance the health of those with mental disorders. Smoking cessation is a significant need. Tobacco-related cancer, heart disease and lung disease are the leading causes of death for individuals with serious mental illness [8]. The prevalence of smoking among people with mental disorders was higher in the 2007 National Health Interview Survey than the prevalence among people without mental disorders [9] and has been reported as 2 to 4 times greater among individuals with serious mental illness [10]. While the rate of smoking among Californians is lower than the rest of the nation, the smoking rate among those with mental disorders or psychological distress is unknown.

In addition to the well-established risks of smoking, people with mental illness also risk diminished effects of their psychotherapeutic drugs. Tobacco smoking induces the metabolism of a number of psychiatric medications, resulting in reduced therapeutic blood levels [11]. Tobacco smoking may also contribute to psychological distress in the now minority population that smokes.

Many mental health practitioners are skeptical about the need for smoking cessation and share low expectations of successful smoking cessation with their patients. A 2006 survey found that psychiatrists of all medical specialties, are the least likely to treat tobacco dependence [12]. It may be true that patients with mental illness present additional challenges to those providing smoking cessation. Pregnant women with a history of a mental disorder and high stress scores have higher odds of continuing smoking [13]. However, many people with serious mental disorders are motivated to attend smoking cessation and are successful [14].

\section{Methods}

\subsection{Research Questions}

The following research questions were determined for this secondary analysis:

- How prevalent are the psychological distress measures among the respondents in the California Health Interview Survey in 2009?

- What are the factors associated with the psychological distress measures in the California Health Interview 
Survey in 2009?

- Which combination of factors is most predictive of psychological distress?

\subsection{California Health Interview Survey}

The public use data base analyzed in this study was collected by the UCLA Center for Health Policy Research in collaboration with the California Department of Public Health and the Department of Health Care Services as the California Health Interview Survey (CHIS). The 2009 data were released on February 16, 2011. CHIS is the nation's largest state health survey. It is a random-dial telephone survey conducted every two years on a wide range of health topics that gives a detailed picture of the health and health care needs of California's large and diverse population. CHIS is conducted in six languages: English, Spanish, Mandarin, Cantonese, Korean and Vietnamese.

\subsection{Variables Selected}

Eighteen of the 576 variables that relate to psychological distress were selected for this analysis. They include experience of psychological distress in the past year; psychological distress in the past month and intermediate indicators of feeling nervous, hopeless, worthless, depressed, and restless and that everything is an effort in the past month. The independent variables were selected as possible variables of association based on literature review. They include: age, gender, marital status, educational attainment, working status, race and ethnicity, born in US, insurance coverage, and smoking. General Health Condition was selected as a comparison variable.

Psychological distress measures

- Psychological distress in past month

- Psychological distress in past year

- Feel worthless in past month

- Feel that everything is an effort

- Feel depressed in past month

- Feel nervous in past month

- Feel hopeless in past month

- Feel restless in past month

\subsection{Data Analysis}

Univariate analyses that report frequencies and percentages were extracted directly from the CHIS data dictionary. They are reported with only minor alterations to table format.

Bivariate analyses were conducted using SPSS version 17. The differences in distribution of each dependent variable (psychological distress and intermediate symptoms) were calculated using chi-square for the nominal and ordinal, discreet variables and Pearson correlation for age. Relative risks were calculated by dividing the percentages in each category who answered "all of the time" by the percentage in the largest category who also answered "all of the time" for each of the study variables.

Multivariate analyses were also calculated using SPSS version 17. The profiles of those at highest risk for each psychological distress variable were determined using stepwise linear regression. All selected variables were included in each analysis.

\subsection{Note}

This research is exempt from institutional review board approval since it is a secondary analysis of data previously collected. The CHIS survey was approved by the UCLA institutional review board.

\section{Result (Tables 1-10)}

\subsection{Univariate Analysis}

Of the 47,614 survey respondents, 28,186 are females (40.8\%) and 19,428 are males (59.2\%) (Table 3), 65\% are non-Hispanic whites (Table 3), 52\% married (Table 5), 76\% were born in the US (Table 6), 42\% were em- 
Table 1. Selected variables for analysis: frequencies and percentages.

\begin{tabular}{|c|c|c|}
\hline & Frequency & Percentage \\
\hline \multicolumn{3}{|c|}{ Experienced Serious Psychological Distress in Past Month } \\
\hline Yes & 1327 & $2.79 \%$ \\
\hline No & 46,004 & $96.62 \%$ \\
\hline Proxy Skipped & 283 & $0.59 \%$ \\
\hline \multicolumn{3}{|c|}{ Experienced Serious Psychological Distress in Past Year } \\
\hline Yes & 2835 & $5.95 \%$ \\
\hline No & 44,496 & $93.45 \%$ \\
\hline Proxy Skipped & 283 & $0.59 \%$ \\
\hline \multicolumn{3}{|c|}{ Feel Worthless Past Month } \\
\hline All of the Time & 360 & $0.76 \%$ \\
\hline Most of the Time & 503 & $1.06 \%$ \\
\hline Some of the Time & 1906 & $4.00 \%$ \\
\hline A Little of the Time & 3500 & $7.35 \%$ \\
\hline Not at All & 41,062 & $86.24 \%$ \\
\hline Proxy Skipped & 283 & $0.59 \%$ \\
\hline \multicolumn{3}{|c|}{ Feel Everything Is an Effort Past Month } \\
\hline All of the Time & 1426 & $2.99 \%$ \\
\hline Most of the Time & 1752 & $3.68 \%$ \\
\hline Some of the Time & 5277 & $11.08 \%$ \\
\hline A Little of the Time & 8840 & $18.57 \%$ \\
\hline Not at All & 30,036 & $63.08 \%$ \\
\hline Proxy Skipped & 283 & $0.59 \%$ \\
\hline \multicolumn{3}{|c|}{ Feel Depressed Past Month } \\
\hline All of the Time & 254 & $0.53 \%$ \\
\hline Most of the Time & 569 & $1.20 \%$ \\
\hline Some of the Time & 2308 & $4.85 \%$ \\
\hline A Little of the Time & 4349 & $9.13 \%$ \\
\hline Not at All & 39,851 & $83.70 \%$ \\
\hline Proxy Skipped & 283 & $0.59 \%$ \\
\hline \multicolumn{3}{|c|}{ Feel Nervous Past Month } \\
\hline All of the Time & 641 & $1.35 \%$ \\
\hline Most of the Time & 1572 & $3.30 \%$ \\
\hline Some of the Time & 6903 & $14.50 \%$ \\
\hline A Little of the Time & 16,002 & $33.61 \%$ \\
\hline Not at All & 22,213 & $46.65 \%$ \\
\hline Proxy Skipped & 283 & $0.59 \%$ \\
\hline \multicolumn{3}{|c|}{ Feel Hopeless Past Month } \\
\hline All of the Time & 279 & $0.59 \%$ \\
\hline Most of the Time & 657 & $1.38 \%$ \\
\hline Some of the Time & 2727 & $5.73 \%$ \\
\hline A Little of the Time & 6482 & $13.61 \%$ \\
\hline Not at All & 37,186 & $78.10 \%$ \\
\hline Proxy Skipped & 283 & $0.59 \%$ \\
\hline \multicolumn{3}{|c|}{ Feel Restless Past Month } \\
\hline All of the Time & 858 & $1.80 \%$ \\
\hline Most of the Time & 1357 & $2.85 \%$ \\
\hline Some of the Time & 6857 & $14.40 \%$ \\
\hline
\end{tabular}




\section{Continued}

\begin{tabular}{|c|c|c|c|}
\hline A Little of the Time & 12517 & $26.29 \%$ & \\
\hline Not at All & 35,742 & $54.06 \%$ & \\
\hline Proxy Skipped & 283 & $0.59 \%$ & \\
\hline \multicolumn{4}{|c|}{ General Health Conditions } \\
\hline Excellent & 9144 & $19.14 \%$ & \\
\hline Very Good & 15,490 & $32.53 \%$ & \\
\hline Good & 13,658 & $28.68 \%$ & \\
\hline Fair & 6878 & $14.45 \%$ & \\
\hline Poor & 2474 & $5.02 \%$ & \\
\hline \multicolumn{4}{|c|}{ Insurance Covers Treatment for Mental Health Problems* } \\
\hline Inapplicable & 41,028 & $86.17 \%$ & \\
\hline Yes & 4521 & $9.50 \%$ & $71 \%$ of Applicable \\
\hline No & 1184 & $2.49 \%$ & 18\% of Applicable \\
\hline No Insurance & 598 & $1.26 \%$ & 9\% of Applicable \\
\hline Proxy Skipped & 283 & $0.59 \%$ & \\
\hline
\end{tabular}

"Asked of those who had experienced mental health problems.

Table 2. Correlation of psychological distress by age.

\begin{tabular}{cc} 
Variable & Pearson correlation value \\
\hline Serious psychological distress in past year & $-0.028^{* *}$ \\
Serious psychological distress in past month & $-0.083^{* *}$ \\
Feel nervous in past month & $0.071^{* *}$ \\
Feel hopeless in past month & $0.027^{* *}$ \\
Feel restless in past month & $0.096^{* *}$ \\
Feel depressed in past month & $-0.009^{*}$ \\
Feel everything is an effort in past month & $0.038^{* *}$ \\
Feel worthless in past month & $-0.036^{* *}$ \\
\hline
\end{tabular}

Table 3. Relative risks of psychological symptoms by gender.

\begin{tabular}{|c|c|c|c|c|}
\hline \multicolumn{5}{|l|}{$\mathrm{n}=47,614$} \\
\hline 28,186 & Females & & & \\
\hline 19,428 & Males & & & \\
\hline Variable & Chi-square & df & $\begin{array}{c}\text { Asymp. } \\
\text { Sig. (2-sided) }\end{array}$ & Relative risk $^{*}$ \\
\hline Psychological distress in past month & 51.33 & 2 & 0.000 & 1.45 \\
\hline Psychological distress in past year & 112.52 & 2 & 0.000 & 1.45 \\
\hline Feel worthless in past month & 49.48 & 5 & 0.000 & 0.88 \\
\hline Feel that everything is an effort in past month & 87.96 & 5 & 0.000 & 0.94 \\
\hline Feel depressed in past month & 65.64 & 5 & 0.000 & 1.2 \\
\hline Feel nervous in past month & 153.13 & 5 & 0.000 & 1.37 \\
\hline Feel hopeless in past month & 73.99 & 5 & 0.000 & 1.2 \\
\hline Feel restless in past month & 83.15 & 5 & 0.000 & 0.89 \\
\hline Poor general health condition & 10.37 & 4 & 0.035 & 1.10 \\
\hline Insurance covers mental health treatment & 231.29 & 4 & 0.000 & 1.54 \\
\hline
\end{tabular}

*Females compared to males for those who answered "all the time".

ployed full-time (Table 7), 23\% had a bachelor's degree (Table 8), 89\% had health insurance (Table 9), and 11\% smoked cigarettes (Table 10). When asked if their insurance covers treatment for mental illnesses, $71 \%$ of those 
Table 4. Relative risks of psychological symptoms by ethnicity.

\begin{tabular}{|c|c|c|c|c|c|c|c|c|c|c|c|}
\hline \multicolumn{12}{|c|}{$\mathrm{n}=47,614$} \\
\hline & 8307 & & & & & Hispanic & & & $(17.4$ & $45 \%)$ & \\
\hline & 31,167 & & & & & White, Non-Hispanic & & & $(65.4$ & $46 \%)$ & \\
\hline & 1852 & & & & African-A & American Only, Non- & -Hispanic & & $(3.8$ & $39 \%)$ & \\
\hline & 354 & & & Americ & an Indian/ & /Alaskan Native Onl & ly, Non-His & spanic & $(0.7$ & 74\%) & \\
\hline & 4852 & & & & Asia & an Only, Non-Hispar & anic & & $(10.1$ & $19 \%)$ & \\
\hline & 66 & & & Nativ & ve Hawaiia & an/Pacific Islanders, & Non-Hispa & anic & $(0.1$ & 14\%) & \\
\hline & 86 & & & & & Other, Non-Hispanic & & & $(0.1$ & 18\%) & \\
\hline & 1016 & & & & Two or 1 & More Races, Non-H & Hispanic & & $(2.1$ & $13 \%)$ & \\
\hline Variable & Chi-Square & $\mathrm{df}$ & $\begin{array}{l}\text { Asymp. } \\
\text { Sig. } \\
\text { (2-sided) }\end{array}$ & $\begin{array}{l}\text { White, } \\
\text { Non-Hispanic }\end{array}$ & * Hispanic & African-American & $\begin{array}{l}\text { American } \\
\text { Indian }\end{array}$ & Asian & $\begin{array}{c}\text { Native } \\
\text { Hawaiian/Pacific } \\
\text { Islander }\end{array}$ & Other & $\begin{array}{l}\text { Two or } \\
\text { More } \\
\text { Races }\end{array}$ \\
\hline $\begin{array}{c}\text { Psychological } \\
\text { distress in past } \\
\text { month }\end{array}$ & 138.1 & 14 & 0.000 & 1.00 & 1.70 & 1.74 & 3.09 & 1.26 & 1.30 & 0 & 2.00 \\
\hline $\begin{array}{c}\text { Psychological } \\
\text { distress in past } \\
\text { year }\end{array}$ & 165.6 & 14 & 0.000 & 1.00 & 1.43 & 1.40 & 2.19 & 0.94 & 1.43 & 0.89 & 2.09 \\
\hline $\begin{array}{l}\text { Feel worthless } \\
\text { in past month }\end{array}$ & 299.4 & 35 & 0.000 & 1.00 & 1.83 & 1.83 & 2.83 & 1.50 & 0 & 0 & 2.83 \\
\hline $\begin{array}{l}\text { Feel that } \\
\text { everything is } \\
\text { an effort in } \\
\text { past month }\end{array}$ & 332.9 & 35 & 0.000 & 1.00 & 1.71 & 2.38 & 3.54 & 1.34 & 2.54 & 1.46 & 1.96 \\
\hline $\begin{array}{l}\text { Feel depressed } \\
\text { in past month }\end{array}$ & 1075.9 & 35 & 0.000 & 1.00 & 3.34 & 3.00 & 5.67 & 2.67 & 0 & 0 & 2.34 \\
\hline $\begin{array}{l}\text { Feel nervous in } \\
\text { past month }\end{array}$ & 331.4 & 35 & 0.000 & 1.00 & 1.91 & 1.64 & 2.09 & 1.55 & 0 & 3.18 & 1.55 \\
\hline $\begin{array}{l}\text { Feel hopeless } \\
\text { in past month }\end{array}$ & 770.7 & 35 & 0.000 & 1.00 & 3.00 & 1.75 & 1.50 & 2.00 & 0 & 0 & 2.50 \\
\hline $\begin{array}{l}\text { Feel restless in } \\
\text { past month }\end{array}$ & 533.3 & 35 & 0.000 & 1.00 & 1.44 & 1.38 & 3.50 & 0.623 & 0 & 2.94 & 3.06 \\
\hline $\begin{array}{c}\text { Poor general } \\
\text { health condition }\end{array}$ & 2485.4 & 28 & 0.000 & 1.00 & 1.31 & 1.81 & 3.24 & 2.17 & 2.52 & 0.55 & 1.86 \\
\hline $\begin{array}{l}\text { Insurance covers } \\
\text { mental health } \\
\text { treatment }\end{array}$ & 492.5 & 28 & 0.000 & 1.00 & 0.67 & 0.96 & 0.98 & 0.40 & 1.13 & 0.65 & 1.25 \\
\hline
\end{tabular}

"Relative risk compared to white, those who answered "all of the time”.

who recalled having the need for treatment reported that their insurance included coverage (Table 1).

Table 1 lists the frequencies and percentages for each of the selected dependent variables. The respondents reported these psychological distress measures at least a little of the time:

- $54 \%$ nervous

- $46 \%$ restless

- $36 \%$ everything is an effort

- $22 \%$ hopeless 
Table 5. Relative risks of psychological symptoms by marital status.

\begin{tabular}{|c|c|c|c|c|c|c|c|}
\hline \multicolumn{8}{|l|}{$\mathrm{n}=47,614$} \\
\hline 24,936 & \multicolumn{4}{|c|}{ Married } & \multicolumn{3}{|c|}{$(52.37 \%)$} \\
\hline 2336 & \multicolumn{4}{|c|}{ Living with a partner } & \multicolumn{3}{|c|}{$(4.91 \%)$} \\
\hline 13,360 & \multicolumn{4}{|c|}{ Widowed, separated or divorced } & \multicolumn{3}{|c|}{$(28.06 \%)$} \\
\hline 6982 & \multicolumn{4}{|c|}{ Never married } & \multicolumn{3}{|c|}{$(14.66 \%)$} \\
\hline Variable & Chi-Square & df & $\begin{array}{l}\text { Asymp. Sig. } \\
\text { (2-sided) }\end{array}$ & Married & $\begin{array}{l}\text { Living with } \\
\text { Partner }\end{array}$ & $\begin{array}{c}\text { Widowed, Separated } \\
\text { or Divorced }\end{array}$ & $\begin{array}{l}\text { Never } \\
\text { Married }\end{array}$ \\
\hline Psychological distress in past month & 241.28 & 6 & 0.000 & 1.00 & 2.22 & 2.22 & 2.57 \\
\hline Psychological distress in past year & 402.43 & 6 & 0.000 & 1.00 & 2.24 & 1.80 & 2.17 \\
\hline Feel worthless in past month & 527.82 & 15 & 0.000 & 1.00 & 1.75 & 3.25 & 2.25 \\
\hline Feel that everything is an effort in past month & 752.83 & 15 & 0.000 & 1.00 & 1.65 & 1.46 & 1.58 \\
\hline Feel depressed in past month & 564.39 & 15 & 0.000 & 1.00 & 2.34 & 3.00 & 2.34 \\
\hline Feel nervous in past month & 613.42 & 15 & 0.000 & 1.00 & 1.70 & 1.90 & 1.50 \\
\hline Feel hopeless in past month & 862.50 & 15 & 0.000 & 1.00 & 1.75 & 2.25 & 1.75 \\
\hline Feel restless in past month & 681.08 & 15 & 0.000 & 1.00 & 1.79 & 1.64 & 1.64 \\
\hline Poor general health condition & 700.65 & 12 & 0.000 & 1.00 & 1.08 & 2.15 & 1.03 \\
\hline Insurance covers mental health treatment & 678.95 & 12 & 0.000 & 1.00 & 1.33 & 1.25 & 1.55 \\
\hline
\end{tabular}

*Relative risk compared to married, those who answered "all of the time”.

Table 6. Relative risks of psychological symptoms by US born.

\begin{tabular}{|c|c|c|c|c|}
\hline \multicolumn{5}{|l|}{$\mathrm{n}=47,614$} \\
\hline 36,133 & \multicolumn{2}{|l|}{ Born in US } & \multicolumn{2}{|c|}{$(75.89 \%)$} \\
\hline 11,481 & \multicolumn{2}{|l|}{ Born outside US } & \multicolumn{2}{|c|}{$(24.11 \%)$} \\
\hline Variable & Chi-Square & $\mathrm{df}$ & Asymp. Sig. (2-sided) & Relative Risk $^{*}$ \\
\hline Psychological distress in past month & 53.0 & 2 & 0.000 & 1.44 \\
\hline Psychological distress in past year & 20.5 & 2 & 0.000 & 1.09 \\
\hline Feel worthless in past month & 150.5 & 5 & 0.000 & 1.43 \\
\hline Feel that everything is an effort in past month & 35.9 & 5 & 0.000 & 1.25 \\
\hline Feel depressed in past month & 802.1 & 5 & 0.000 & 2.5 \\
\hline Feel nervous in past month & 71.06 & 5 & 0.000 & 3.25 \\
\hline Feel hopeless in past month & 463.8 & 5 & 0.000 & 2.75 \\
\hline Feel restless in past month & 64.0 & 5 & 0.000 & 0.84 \\
\hline Poor general health condition & 1439.7 & 4 & 0.035 & 1.47 \\
\hline Insurance covers mental health & 342.2 & 4 & & 0.48 \\
\hline
\end{tabular}

*Born outside US compared to born inside US for those who said "all of the time".

- $13 \%$ depressed

- $13 \%$ worthless

Almost 3\% experienced psychological distress in the month prior to the survey. Almost $6 \%$ experienced serious psychological distress in the year prior to the survey. Also, $5 \%$ of the respondents self-reported "poor" health.

\subsection{Bivariate Analysis}

Age is positively correlated with feeling nervous, hopeless, and restless and that everything is an effort, but negatively correlated with serious distress in past month or year and feelings of depression and worthlessness. The correlations are very weak and do not account for much of the variation in psychological symptoms (Table 2). 
Table 7. Relative risks of psychological symptoms by working status.

\begin{tabular}{|c|c|c|c|c|c|c|c|c|}
\hline \multicolumn{9}{|l|}{$\mathrm{n}=47,614$} \\
\hline 20,252 & \multicolumn{5}{|c|}{ Full time } & \multicolumn{3}{|c|}{$(42.53 \%)$} \\
\hline 4010 & \multicolumn{5}{|c|}{ Part time } & \multicolumn{3}{|c|}{$(8.42 \%)$} \\
\hline 240 & \multicolumn{5}{|c|}{ Employed, not at work } & \multicolumn{3}{|c|}{$(0.50 \%)$} \\
\hline 2541 & \multicolumn{5}{|c|}{ Unemployed, looking for work } & \multicolumn{3}{|c|}{$(5.29 \%)$} \\
\hline 20,591 & \multicolumn{5}{|c|}{ Unemployed, not looking for work } & \multicolumn{3}{|c|}{$(43.25 \%)$} \\
\hline Variable & Chi-Square & df & $\begin{array}{l}\text { Asymp. Sig. } \\
\text { (2-sided) }\end{array}$ & Full Time* & $\begin{array}{l}\text { Part } \\
\text { Time }\end{array}$ & $\begin{array}{l}\text { Employed, } \\
\text { Not at Work }\end{array}$ & $\begin{array}{l}\text { Unemployed, } \\
\text { Looking for } \\
\text { Work }\end{array}$ & $\begin{array}{l}\text { Unemployed, } \\
\text { Not Looking } \\
\text { for Work }\end{array}$ \\
\hline Psychological distress in past month & 649.6 & 8 & 0.000 & 1.00 & 1.57 & 2.07 & 3.86 & 2.00 \\
\hline Psychological distress in past year & 565.8 & 8 & 0.000 & 1.00 & 1.46 & 1.17 & 2.46 & 1.41 \\
\hline Feel worthless in past month & 992.4 & 20 & 0.000 & 1.00 & 2.50 & 4.00 & 6.50 & 6.00 \\
\hline $\begin{array}{l}\text { Feel that everything is an } \\
\text { effort in past month }\end{array}$ & 801.7 & 20 & 0.000 & 1.00 & 0.90 & 1.81 & 2.23 & 1.86 \\
\hline Feel depressed in past month & 882.9 & 20 & 0.000 & 1.00 & 3.00 & 2.00 & 4.00 & 4.00 \\
\hline Feel nervous in past month & 880.7 & 20 & 0.000 & 1.00 & 1.65 & 0.55 & 2.76 & 2.45 \\
\hline Feel hopeless in past month & 1069.1 & 20 & 0.000 & 1.00 & 1.67 & 2.67 & 4.34 & 2.67 \\
\hline Feel restless in past month & 895.9 & 20 & 0.000 & 1.00 & 1.08 & 0.62 & 2.70 & 1.62 \\
\hline Poor general health condition & 2732.1 & 16 & 0.000 & 1.00 & 1.40 & 3.07 & 2.47 & 6.47 \\
\hline $\begin{array}{l}\text { Insurance covers mental health } \\
\text { treatment }\end{array}$ & 952.2 & 16 & 0.000 & 1.00 & 1.01 & 0.50 & 1.03 & 0.85 \\
\hline
\end{tabular}

"Relative risk compared to full time, those who answered "all of the time".

All selected dependent measures (psychological distress markers, general health conditions and insurance that covers mental health) varied significantly by all selected demographic variables and by smoking status. Chisquare statistics were calculated and all except one p-value was $<0.001^{*}$. The exception was the relationship between poor general health and gender which has a p-value of 0.035 .

The relative risks were calculated comparing the prevalence of the psychological symptom or measure in those of the largest category in each variable with those in the other categories (Tables 1-10).

Women are more likely to report psychological distress (1.45 more likely in the past month or year), feeling depressed (1.2 times more likely), hopeless (1.2 times more likely), poorer general health (1.1 times more often) and having insurance that covers treatment of mental health (1.54 times more often). Men are more likely to report feeling worthless (1.1 times more often) and restless (1.1 times more often) (Table 3).

As indicated in Table 4, Hispanics, African-Americans, American Indians and those of two or more races more frequently report all of the measures of psychological distress than whites. Hispanics, African-Americans and American Indians are also less likely to have insurance that covers treatment of mental disorders. Asians, Pacific Islanders and others report some symptoms more often and some less often than whites.

Marriage predicts lower levels of all psychological distress measures. Those who are widowed, separated or divorced express the most feelings of worthlessness and depression (Table 5).

Table 6 indicates much higher risk of psychological distress measures and less insurance coverage among those with less than college education. The group who has attended some graduate school shows lower risk than those with a BS or BA degree. The relationship between psychological distress measures and education is not linear. The protective effect diminishes from master's degree to doctorate degrees. Those with $\mathrm{PhD}$ are more likely to report feeling depressed than those with bachelor's degrees.

The unemployed report more psychological distress with those looking for work at the highest risk. The exception is that those not looking for working are more likely to report poor general health (Table 7). Those born outside of the US report more symptoms with the exception of restlessness. They are also less likely to have health insurance that covers treatment of mental disorders (Table 8). Those at the greatest risk are the least likely to have insurance that covers treatment of mental disorders (Table 9). Smokers are 4.5 times more likely to report feeling depressed in the past month (Table 10). 
Table 8. Relative risks of psychological symptoms by educational attainment.

(a)

\begin{tabular}{|c|c|c|c|c|c|c|c|c|c|}
\hline $\mathrm{n}=47,614$ & & & & & & & & & \\
\hline 230 & \multicolumn{4}{|c|}{ No formal education } & \multicolumn{5}{|c|}{$(0.48 \%)$} \\
\hline 2408 & \multicolumn{4}{|c|}{ Grade 1 - 8} & \multicolumn{5}{|c|}{$(5.06 \%)$} \\
\hline 2196 & \multicolumn{4}{|c|}{ Grade 9 - 11} & \multicolumn{5}{|c|}{$(4.61 \%)$} \\
\hline 10,458 & \multicolumn{4}{|c|}{ Grade 12/HS diploma } & \multicolumn{5}{|c|}{$(21.96 \%)$} \\
\hline 8041 & \multicolumn{4}{|c|}{ Some college } & \multicolumn{5}{|c|}{$(16.89 \%)$} \\
\hline 1374 & \multicolumn{4}{|c|}{ Vocational school } & \multicolumn{5}{|c|}{$(2.89 \%)$} \\
\hline 3507 & \multicolumn{4}{|c|}{ AA or AS degree } & \multicolumn{5}{|c|}{$(7.37 \%)$} \\
\hline 10,842 & \multicolumn{4}{|c|}{ BA or BS degree } & \multicolumn{5}{|c|}{$(22.77 \%)$} \\
\hline 742 & \multicolumn{4}{|c|}{ Some grad school } & \multicolumn{5}{|c|}{$(1.56 \%)$} \\
\hline 5579 & \multicolumn{4}{|c|}{ MA or MS degree } & \multicolumn{5}{|c|}{$(11.72 \%$} \\
\hline 5579 & \multicolumn{4}{|c|}{ PHD or equivalent } & \multicolumn{5}{|c|}{$(4.70 \%)$} \\
\hline Variable & Chi-Square & df & $\begin{array}{l}\text { Asymp. Sig. } \\
\text { (2-sided) }\end{array}$ & $\begin{array}{c}\text { BA or } \\
\text { BS Degree* }\end{array}$ & $\begin{array}{l}\text { No Formal } \\
\text { Education }\end{array}$ & $\begin{array}{c}\text { Grade } \\
1-8\end{array}$ & $\begin{array}{l}\text { Grade } \\
9-11\end{array}$ & $\begin{array}{l}\text { Grade 12/HS } \\
\text { Diploma }\end{array}$ & $\begin{array}{l}\text { Some } \\
\text { College }\end{array}$ \\
\hline Psychological distress in past month & 469.0 & 20 & 0.000 & 1.00 & 3.00 & 4.13 & 3.88 & 2.00 & 1.94 \\
\hline Psychological distress in past year & 368.8 & 20 & 0.000 & 1.00 & 1.51 & 2.12 & 2.30 & 1.56 & 1.60 \\
\hline Feel worthless in past month & 850.3 & 50 & 0.000 & 1.00 & 10.75 & 6.25 & 5.50 & 2.50 & 1.50 \\
\hline $\begin{array}{c}\text { Feel that everything is an effort in } \\
\text { past month }\end{array}$ & 792.2 & 50 & 0.000 & 1.00 & 2.53 & 3.41 & 3.53 & 2.29 & 1.94 \\
\hline Feel depressed in past month & 1521.8 & 50 & 0.000 & 1.00 & 43.00 & 20.00 & 16.00 & 6.00 & 4.00 \\
\hline Feel nervous in past month & 595.5 & 50 & 0.000 & 1.00 & 5.00 & 5.43 & 4.29 & 2.14 & 2.00 \\
\hline Feel hopeless in past month & 1144.2 & 50 & 0.000 & 1.00 & 8.50 & 13.00 & 10.00 & 3.50 & 1.50 \\
\hline Feel restless in past month & 538.6 & 50 & 0.000 & 1.00 & 3.91 & 2.82 & 3.64 & 2.00 & 1.73 \\
\hline Poor general health condition & 5236.7 & 40 & 0.000 & 1.00 & 7.29 & 4.82 & 4.11 & 2.36 & 1.86 \\
\hline Insurance covers mental health treatment & 421.5 & 40 & 0.000 & 1.00 & 0.36 & 0.41 & 0.60 & 0.72 & 0.93 \\
\hline
\end{tabular}

"Relative risk compared to BA or BS, those who answered "all of the time".

(b)

\begin{tabular}{|c|c|c|c|c|c|c|}
\hline Variable & $\begin{array}{l}\text { BA or BS } \\
\text { Degree }^{*}\end{array}$ & $\begin{array}{c}\text { Vocational } \\
\text { School }\end{array}$ & $\begin{array}{l}\text { AA or AS } \\
\text { Degree }\end{array}$ & $\begin{array}{c}\text { Some } \\
\text { Grad School }\end{array}$ & $\begin{array}{l}\text { MA } \\
\text { or MS }\end{array}$ & $\begin{array}{c}\text { PhD or } \\
\text { Equivalent }\end{array}$ \\
\hline Psychological distress in past month & 1.00 & 3.06 & 1.81 & 0.44 & 0.69 & 0.81 \\
\hline Psychological distress in past year & 1.00 & 2.16 & 1.44 & 1.23 & 0.79 & 0.93 \\
\hline Feel worthless in past month & 1.00 & 2.25 & 1.75 & 0 & 0.50 & 0.75 \\
\hline Feel that everything is an effort in past month & 1.00 & 2.41 & 2.06 & 0.47 & 0.76 & 0.71 \\
\hline Feel depressed in past month & 1.00 & 10.00 & 5.00 & 0 & 1.00 & 3.00 \\
\hline Feel nervous in past month & 1.00 & 3.00 & 2.29 & 0.57 & 0.71 & 0.86 \\
\hline Feel hopeless in past month & 1.00 & 4.00 & 2.50 & 1.50 & 1.00 & 1.00 \\
\hline Feel restless in past month & 1.00 & 2.91 & 1.73 & 0.64 & 0.73 & 0.55 \\
\hline Poor general health condition & 1.00 & 2.43 & 1.64 & 0.57 & 0.79 & 0.89 \\
\hline Insurance covers mental health treatment & 1.00 & 0.78 & 1.01 & 1.08 & 1.06 & 1.03 \\
\hline
\end{tabular}

"Relative risk compared to BA or BS, those who answered "all of the time".

\subsection{Multivariate-Stepwise Linear Regression Analysis}

The following profiles emerged for each of the psychological distress symptoms and measures:

Serious psychological distress in past year

- Unemployed

- Smoker

- Less than BS education 
Table 9. Relative risks of psychological symptoms by currently insured.

\begin{tabular}{|c|c|c|c|c|}
\hline \multicolumn{5}{|l|}{$\mathrm{n}=47,614$} \\
\hline 42,468 & \multicolumn{2}{|l|}{ Currently insured } & \multicolumn{2}{|c|}{$(89.19 \%)$} \\
\hline 5146 & \multicolumn{2}{|l|}{ Currently uninsured } & \multicolumn{2}{|c|}{$(10.81 \%)$} \\
\hline Variable & Chi-Square & df & Asymp. Sig. (2-sided) & Relative Risk $^{*}$ \\
\hline Psychological distress in past month & 141.9 & 2 & 0.000 & 2.04 \\
\hline Psychological distress in past year & 208.6 & 2 & 0.000 & 1.87 \\
\hline Feel worthless in past month & 321.1 & 5 & 0.000 & 2.00 \\
\hline Feel that everything is an effort in past month & 273.1 & 5 & 0.000 & 1.68 \\
\hline Feel depressed in past month & 566.2 & 5 & 0.000 & 1.80 \\
\hline Feel nervous in past month & 231.2 & 5 & 0.000 & 2.08 \\
\hline Feel hopeless in past month & 903.2 & 5 & 0.000 & 3.00 \\
\hline Feel restless in past month & 305.9 & 5 & 0.000 & 1.94 \\
\hline Poor general health condition & 464.8 & 4 & 0.035 & 1.04 \\
\hline
\end{tabular}

*Uninsured compared to insured.

Table 10. Relative risks of psychological symptoms for smokers.

\begin{tabular}{|c|c|c|c|c|}
\hline \multicolumn{5}{|l|}{$\mathrm{n}=47,614$} \\
\hline 5537 & \multicolumn{2}{|c|}{ Smokers } & \multicolumn{2}{|c|}{$(11.6 \%)$} \\
\hline 42,077 & \multicolumn{2}{|c|}{ Non-smokers } & \multicolumn{2}{|c|}{$(88.4 \%)$} \\
\hline Variable & Chi-Square & df & Asymp. Sig. (2-sided) & Relative Risk ${ }^{*}$ \\
\hline Psychological distress in past month & 454.39 & 2 & 0.000 & 3.23 \\
\hline Psychological distress in past year & 697.65 & 2 & 0.000 & 2.82 \\
\hline Feel worthless in past month & 446.39 & 5 & 0.000 & 3.00 \\
\hline Feel that everything is an effort in past month & 698.01 & 5 & 0.000 & 2.44 \\
\hline Feel depressed in past month & 582.85 & 5 & 0.000 & 4.57 \\
\hline Feel nervous in past month & 642.88 & 5 & 0.000 & 3.09 \\
\hline Feel hopeless in past month & 647.74 & 5 & 0.000 & 2.8 \\
\hline Feel restless in past month & 895.56 & 5 & 0.000 & 3.5 \\
\hline
\end{tabular}

*Compared to non-smokers for those who answered "all of the time".

- Unmarried

Serious psychological distress in past month

- Unemployed

- Younger age

- Smoker

- Minority ethnicity

- Less than BS education

Feel nervous in past month

- Smoker

- Older age

- Unemployed

- Unmarried

- Less than BS education

Feel hopeless in past month

- Unemployed

- Minority ethnicity

- Unmarried

- Born in US 
- Older age

- Less than BS education

Feel restless in past month

- Smoker

- Older age

- Unemployed

- Born in US

- Unmarried

- Less than BS education

Feel depressed in past month

- Unemployed

- Minority ethnicity

- Smoker

- Born outside US

- Unmarried

- Less than BS education

Feel everything is an effort in past month

- Unemployed

- Minority ethnicity

- Smoker

- Born outside US

- Unmarried

- Less than BS education

Feel worthless in past month

- Unemployed

- Smoker

- Unmarried

- Born outside US

- Less than BS education

- Minority ethnicity

\section{Discussion}

The magnitude of age and gender differences is less than expected. Age and gender are often emphasized in the professional literature as significant risk factors for mental illnesses; however, the results of this study find that other demographic variables contribute more to the mental health disparities when measuring psychological distress.

The experience of psychological distress symptoms is higher among most minority groups in California especially regarding depression and feeling worthless. In addition, those born outside the US are more likely to feel nervous and hopeless. These serious mental health disparities are often overshadowed by the physical health disparities regarding heart disease, cancers and injuries. However, since there are significant links between mental and physical health, mental health disparities also deserve attention.

Marriage correlates with more positive mental health. It cannot be determined whether marriage leads to better mental health or that mentally healthy people are more likely to marry or both. These data do show that there are critical life events that warrant the attention of public mental health planners like divorce and widowhood.

Educational attainment less than a bachelor's degree is associated with more distress symptoms especially depression, feeling hopeless and worthless. Educational attainment beyond a bachelor's degree is associated with less distress symptoms except regarding depression. The largest group by educational attainment holds a bachelor's degree. A four-year college degree has become the expectation in the United States. 57\% of Californians who responded to the survey had less than four years of college and experienced the highest relative risks of psychological distress in all of this study's analyses.

Unemployment rates in the United States as a whole and California specifically have been at the highest rates since the 1930s. The unemployed who are looking for work are at higher risk of feeling worthless and hopeless. 
These symptoms are precursors to serious mental disorders, suicide and physical disorders. Coupled with unemployment is lack of health insurance coverage. In addition, those with health insurance may not have coverage for treatment of mental illnesses. People at the greatest risk of psychological distress are also less likely to have insurance that covers their symptoms.

In addition to the demographic correlates with psychological distress, one behavioral variable was examined. Smoking is correlated with psychological distress measures especially feeling depressed. Smoking is the leading cause of preventable death in the United States and the mentally ill are at even higher risk. Smokers are also more likely to experience psychological distress. Smokers with the dual risks of mental and physical illnesses are especially in need of effective cessation programs that deal with nicotine addiction and address negative feelings among smokers.

\subsection{Limitations}

The survey response rate for 2009 is not yet published. However, the statewide response rate for the landline/list sample in the 2007 adult interview was 52.8 percent, a decrease of 1.2 percentage points from CHIS 2005. Larger counties had lower response rates than smaller counties. To address the possible bias of landline surveys, a sample of cellular phone surveys were conducted in 2009.

Since the CHIS is specific to California, the results cannot be generalized to the entire nation. However, one-fifth of the nation's population does live in California. Cross-sectional measurements of this type cannot be used for identifying temporal sequence and causation.

\subsection{Further Studies}

In addition to the closed-ended questions in the survey, additional qualitative research may increase the depth of understanding of the associations among psychological distress symptoms and measures and demographic variables. A mixed methods approach could assist in understanding the causative aspects of the associations and may shed light on possible avenue for treatment.

Prospective or case-control studies could investigate the temporal and possible causative link between smoking and psychological distress. Smoking may contribute to the pathway to psychological distress by changing neurotransmission in the brains of smokers. Psychological distress may contribute to smoking initiation and difficulty with cessation. Alternatively both smoking and psychological distress may have other similar causative factors.

\section{Conclusions}

Primary care physicians and nurse practitioners may be able to identify patients at higher risk of psychological distress. Smokers and others who are identified by profile risk characteristics can be given additional screening for psychological distress and mental disorders. This can lead to more appropriate referrals for diagnosis and treatment.

Public health program planners can identify groups of people at higher risk for primary prevention interventions. Additional attention can be devoted to the mental health needs of smokers who are targeted for cessation activities. The unemployed who are looking for work may benefit from support groups and attention to their mental health. Public health educators can plan mass media campaigns tailored to the mental health needs of the newly divorced or widowed. Community health workers who have been shown to be effective in programs to control chronic diseases can be trained to combat psychological distress as well. Public mental health programs can enhance the lives of countless people in our communities.

\section{References}

[1] Farr, S.L., Bitsko, R.H. and Hayes, D.K. (2010) Mental Health Access to Services among US Women of Reproductive Age. American Journal of Obstetrics and Gynecology, 203, 542-549. http://dx.doi.org/10.1016/j.ajog.2010.07.007

[2] Robinson, K.M. (2010) Policy Issues in Mental Health among the Elderly. Nursing Clinics of North America, 45, 627634. http://dx.doi.org/10.1016/j.cnur.2010.06.005

[3] Goins, R.T. and Pilkerton, C.S. (2010) Comorbidity among Older American Indians: The Native Elderly Care Study. Journal of Cross Cultural Gerontology, 25, 343-354. http://dx.doi.org/10.1007/s10823-010-9119-5 
[4] Mezuk, B., Rafferty, J.A., Kiarri, N., Hudson, D., Abdou, C.M., Hedwig, L., Eaton, W. and Jackson, J. (2010) Reconsidering the Role of Social Disadvantage in Physical and Mental Health: Stressful Life Events, Health Behaviors, Race and Depression. American Journal of Epidemiology, 172, 1238-1249. http://dx.doi.org/10.1093/aje/kwq283

[5] Needham, B.L., Epel, E.S., Adler, N.E. and Kiefe, C. (2010) Trajectories of Change in Obesity and Symptoms of Depression: The CARDIA Study. American Journal of Public Health, 100, 1040-1046. http://dx.doi.org/10.2105/AJPH.2009.172809

[6] Perry, G.S., Presley-Cantrell, L.R. and Dhingra, S. (2010) Addressing Mental Health Promotion in Chronic Disease Prevention and Health Promotion. American Journal of Public Health, 100, 2337-2339. http://dx.doi.org/10.2105/AJPH.2010.205146

[7] Salum, G.A., Polanczyk, G.V. and Miguel, E.C. (2010) Effects of Childhood Development on Late-Life Mental Disorders. Current Opinions in Psychiatry, 23, 498-503. http://dx.doi.org/10.1097/YCO.0b013e32833ead33

[8] Colton, C.W. and Manderscheid, R.W. (2006) Congruencies in Increased Mortality Rates, Years of Potential Life Lost, and Causes of Death among Public Mental Health Clients in Eight States. Prevention of chronic Disease, 3, A42.

[9] McClave, A.K., McKnight-Eily, L.R., Davis, S.P. and Dube, S.R. (2010) Smoking Characteristics of Adults with Selected Lifetime Mental Illnesses: Results from the 2007 National Health Interview Survey. American Journal of Public Health, 100, 2464-2472. http://dx.doi.org/10.2105/AJPH.2009.188136

[10] Lasser, K., Boyd, J.W., Woolhandler, S., Himmelstein, D.U., McCormick, D. and Bor, D.H. (2000) Smoking and Mental Illness: A Population-Based Prevalence Study. Journal of the American Medical Association, 284, 2606-2610. http://dx.doi.org/10.1001/jama.284.20.2606

[11] Zevin, S. and Benowitz, N.L. (1999) Drug Interactions with Tobacco Smoking: An Update. Clinical Pharmokinetics, 36, 425-438. http://dx.doi.org/10.2165/00003088-199936060-00004

[12] American Medical Association (2006) Treatment of Tobacco Dependence. http://www.ama-assn.org/ama/pub/education-careers/continuing-medical-education/cme-credit-offerings/therapeutic-in sights/treatment-tobacco-dependence.page

[13] Holtrop, J.S., Meghea, C. and Raffo, J. (2010) Smoking among Pregnant Women with Medicaid Insurance: Are Mental Health Factors Related? Maternal and Child Health Journal, 14, 971-977. http://dx.doi.org/10.1007/s10995-009-0530-X

[14] Ashton, M., Miller, C.L., Boweden, J.A. and Bertossa, S. (2010) People with Mental Illness Can Tackle Tobacco. Australian and New Zealand Journal of Psychiatry, 44, 1021-1028. 
Scientific Research Publishing (SCIRP) is one of the largest Open Access journal publishers. It is currently publishing more than 200 open access, online, peer-reviewed journals covering a wide range of academic disciplines. SCIRP serves the worldwide academic communities and contributes to the progress and application of science with its publication.

Other selected journals from SCIRP are listed as below. Submit your manuscript to us via either submit@scirp.org or Online Submission Portal.
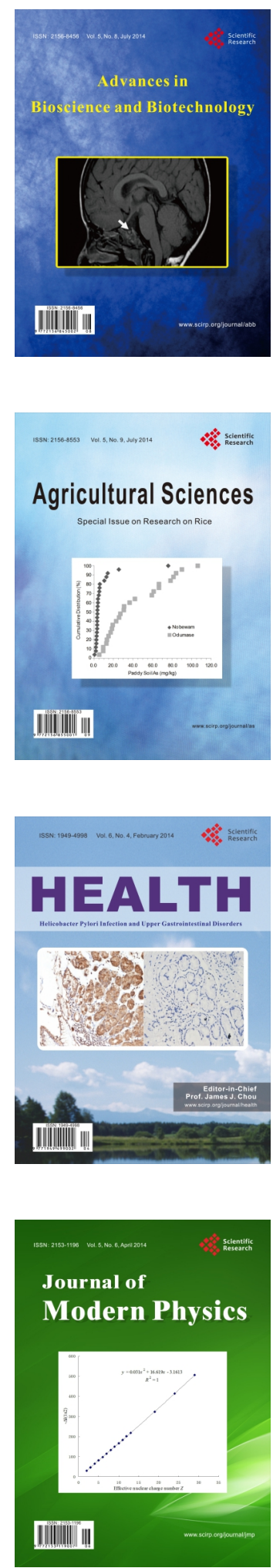
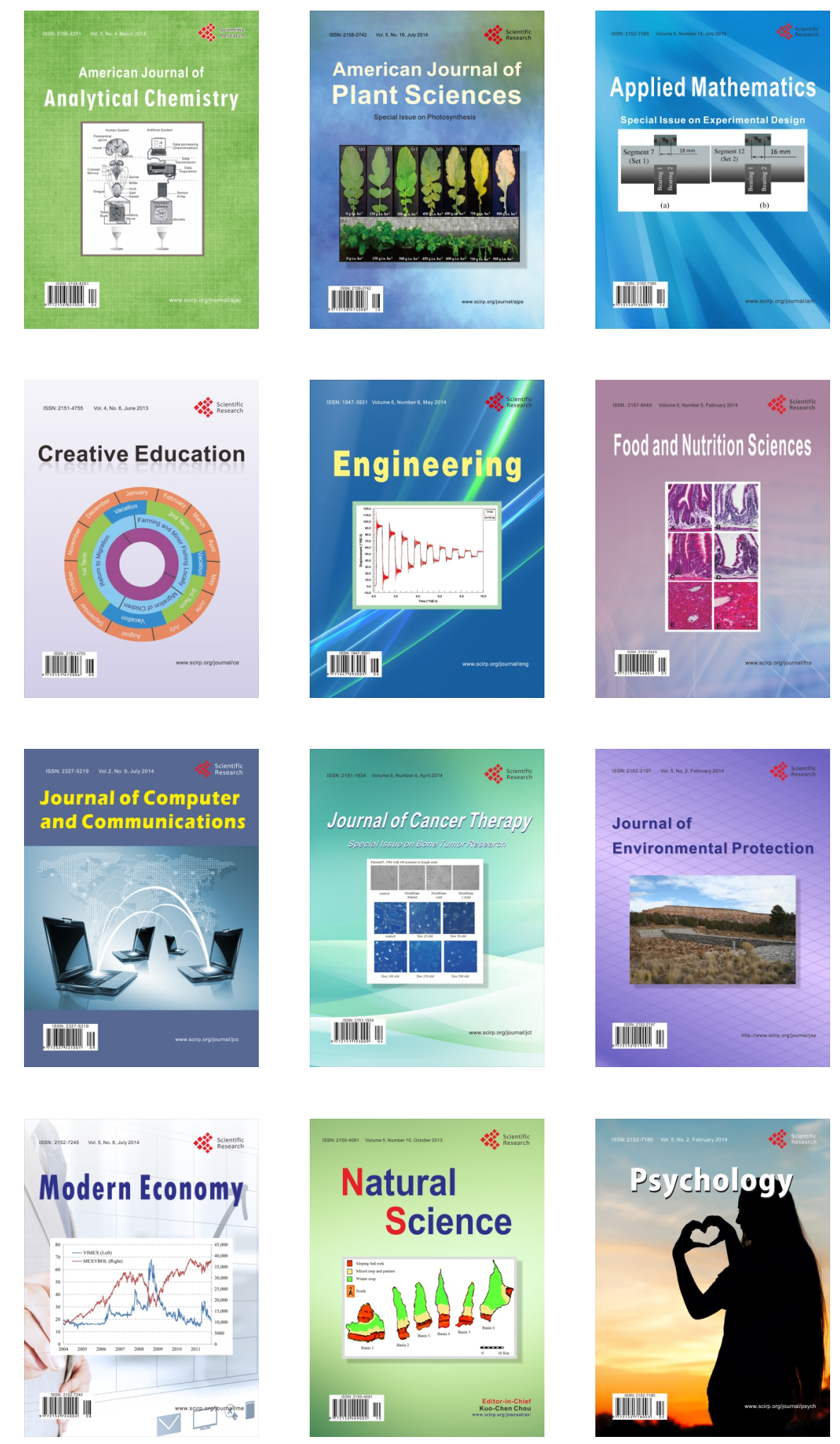